\title{
Detection of Circulating Tumor Cells in Patients with Breast, Prostate, Pancreatic, Colon and Melanoma Cancer: A Blinded Comparative Study Using Healthy Donors
}

\author{
Ioannis Papasotiriou*, Marina Chatziioannou, Konstantina Pessiou, Ippokratis Retsas, \\ Georgia Dafouli, Antigoni Kyriazopoulou, Maria Toloudi, Irene Kaliara, \\ Ioanna Vlachou, Eleni Kourtidou, Vasiliki Kipourou, Evanthia Georgiou, \\ Dimitrios Athanasios Ntanovasilis, Christos Theodosiou, Aikaterini Pantopikou, \\ Panagiotis Apostolou
}

Research Genetic Cancer Centre Ltd. (R.G.C.C. Ltd.), Florina, Greece

Email: *office@rgcc.genlab.com

Received 25 May 2015; accepted 4 July 2015; published 7 July 2015

Copyright (C) 2015 by authors and Scientific Research Publishing Inc.

This work is licensed under the Creative Commons Attribution International License (CC BY).

http://creativecommons.org/licenses/by/4.0/

(c) (i) Open Access

\begin{abstract}
Cancer is a diverse disease characterized by abnormal cell growth and the ability to invade or spread to other parts of the body. Because the yearly cancer rate is increasing, an important area for cancer researchers is to improve the ability to detect and treat cancer early. The current study analyzes the potential of flow cytometry to be used to detect circulating tumor cells (CTCs) in patients with various cancer types and stages. CTCs are cells that have detached from the primary tumor and entered the blood stream in the process of metastasizing to other organs. To determine the accuracy of flow cytometry in detecting CTCs, a comparative study was performed on healthy donors. In this study, blood samples from patients with breast, prostate, pancreatic, colon and skin cancer were analyzed and compared with healthy donors. The data were collected and analyzed statistically with receiver operating characteristic curve analysis. The results indicate that CTCs can be detected in over $83 \%$ of the cancer patients and therefore may be a promising method for diagnosing cancer.
\end{abstract}

\section{Keywords}

Circulating Tumor Cell, Cancer Detection, Diagnosis, Flow Cytometry

\footnotetext{
${ }^{*}$ Corresponding author.
} 


\section{Introduction}

Cancer is associated with high rates of mortality and morbidity worldwide and is the third leading cause of death after cardiovascular and infectious diseases [1]. Established metastatic lesions are the major cause of death in cancer patients, rather than the primary tumor. Scientists have made significant efforts to understand, treat cancer and detect it early; however, the specific mechanisms involved in carcinogenesis and metastasis are not fully understood [2]. It is known that metastasis involves tumor cells invading surrounding tissues and entering the blood or lymphatics [3]. Circulating tumor cells (CTCs) were first observed in 1869 by Thomas Ashworth and have since been of great importance in delineating the metastatic spread of carcinomas. These cells have detached from the primary tumor and flow into the blood or lymphatic circulation creating a secondary tumor [4]. The number of CTCs could be a predictive marker for cancer progression. However, as these cells are rare in cell population, their detection is important [5]. Researchers have developed several assays to detect CTCs for cancer diagnosis. One platform consists of EpCAM antibodies attached to magnetic beads, so the cells are isolated with a magnetic field. Another platform is based in gene expression profiling of CTCs, so the isolation is performed by targeting specific genes. The use of herringbone-chip, an enhanced platform for CTC isolation is also an alternative method for isolation. It is based on the increase of interactions between CTCs and the chip surface which is coated with EpCAM antibodies [6]-[8]. There is a controversy among the scientific community about the effectiveness of each method. The purpose of this study was to evaluate an alternative fluidic-based method to identify CTCs in the blood of cancer patients and to validate its reliability by also examining healthy individuals.

\section{Materials and Methods}

\subsection{Sample Collection}

Blood samples from 30 healthy individuals and 30 patients were collected in sterilized $50 \mathrm{ml}$ falcon tubes (Corning, NY, USA) containing $7 \mathrm{ml}$ 0.02M EDTA (Duchefa Biochemie B.V, Haarlem, The Netherlands) as an anticoagulant. Healthy individuals were identified as healthy or with non-malignant disease by their physicians. The cancer types and stages of the samples used include: Breast cancer, two patients with stage I, two patients with stage II, four patients with stage III and two patients with stage IV; prostate cancer, one patient with stage I, two patients with stage IV and two patients with a non-applicable stage; colon, one patient with stage III, two patients with stage IV and two patients with a non-applicable stage; pancreatic, four patients with stage IV and one with stage III; melanoma, three patients with stage III and two with a non-applicable stage. The quantity of blood collected was $20 \mathrm{ml}$ in both healthy and cancer patients. The samples were cultivated on a roller for 30 minutes and then sent to the laboratory for analysis. The transit of the samples to the laboratory did not exceed 72 hours. The study was performed from January to April of 2015. The samples that were used were collected randomly among cancer and healthy samples, based only on the type of the cancer as well as the stage of the disease and then were analyzed blindly. The breast cancer samples were collected from women with an average age of 58 years old, while the prostate samples from men between 52 - 72 years old. The samples were received both from American and European countries.

\subsection{Samples Stability}

The period between transportation and analysis did not affect the experimental analysis. To ensure this, blood samples were collected from five healthy donors and placed in five different $50 \mathrm{ml}$ falcon tubes. The tubes were then stored at $4^{\circ} \mathrm{C}$, which is the temperature of transportation package. Each day, starting from $0 \mathrm{~h}$, every sample from each donor, was tested by using molecular and cellular assays. In a time window of $0,24,48,72$ and $96 \mathrm{~h}$ of storage, the gene expression of many genes correlated with cell cycle, apoptosis, cytoskeleton, stemness, cytokeratins, growth factors, signaling transduction pathways etc were tested. The same procedure was performed with flow cytometry to study the protein level. Finally, the number of CTCs was measured for every sample each day. Ta data were analyzed and there was not observed any statistically significant difference among the different time periods. Concerning the above experimental data, the transit period, did not affect the analysis of the present study. 


\subsection{Ethical Approval}

This study is not a clinical trial and does not include intervention in patients. All procedures were conducted according to the standards of Safety, Bioethics and Validation. The study was reviewed and approved by Bioethical Committee of Research Genetic Cancer Centre Group. Each patient has consented writing for use of his sample in the present study. The patients retained the right to withdraw their sample until the date when the sample was received at the laboratory and tested.

\subsection{Sample Preparation}

$2 \mathrm{ml}$ of blood was mixed with $2 \mathrm{ml}$ of fetal bovine serum (Gibco, California, USA) in 15-ml centrifuge tubes (Corning, New York, USA) to regain the cells' shape. The samples were then centrifuged at $1200 \mathrm{rpm}$ for 10 minutes at room temperature and the supernatant was discarded. $100 \mu \mathrm{l}$ of sample was transferred to BD Falcon $^{\mathrm{TM}}$ Round-Bottom Tubes $(12 \times 75 \mathrm{~mm}$; BD Biosciences, San Jose, CA) for flow cytometry analysis. Different cancer types required different amounts of staining panels; breast, colon, pancreatic and melanoma cancer samples required four tubes and prostate cancer samples required five tubes. Table 1 shows the panel of antibodies used for each tube.

\subsection{Antibodies}

The following mouse anti-human antibodies were used: anti-cytokeratin (Pan-reactive) monoclonal antibody (Sigma, Taufkirchen, Germany) stained with a Cy5.5 ${ }^{\circledR}$ Conjugation Kit (Abcam, Cambridge, UK), CD227 FITC (AbD Serotec, Oxford, UK), CD63 FITC (Becton Dickinson, New Jersey, USA), CD31 RPE (AbD Serotec, Oxford, UK) and CD45 PE-Cy7 (Invitrogen, California, USA). Human PSMA/FOLH1 Phycoerythrin MAb (RnD Systems, Abingdon, UK) and Human HGF R/c-MET Phycoerythrin MAb (RnD Systems, Abingdon, UK) were also used. All antibodies were used according to the manufacturer's instructions. The antibodies used and their characteristics are presented in Table 2.

\subsection{Staining Procedure}

Because intracellular antibodies were used, the cells required fixation and permeabilization. The samples were therefore stained using LEUCOPERM ${ }^{\mathrm{TM}}$ (AbD Serotec, Oxford, UK) according to the manufacturer's instructions. The only variation from the manufacturer's protocol included a decrease in the incubation time of the samples with Reagent A from 15 to 5 minutes because it caused cell decomposition. After staining, the samples were kept at $4^{\circ} \mathrm{C}$ until analysis.

\subsection{Instrumentation-Data Analysis}

The instrument used to analyze the samples was a BD Accuri C6 cytometer, using two lasers (blue and red; BD

Table 1. Illustration of number of tubes stained per type of cancer.

\begin{tabular}{cccccc}
\hline Number & Tubes & Breast & Prostate & Melanoma & All other types \\
\hline 1 & Unstained-unfixed & $\sqrt{ }$ & $\sqrt{ }$ & $\sqrt{ }$ & $\sqrt{ }$ \\
2 & Unstained-fixed & $\sqrt{ }$ & $\sqrt{ }$ & $\sqrt{ }$ \\
3 & CD31-CD45-pan CK & & $\sqrt{ }$ & \\
4 & cMET-CD45-pan CK & & $\sqrt{ }$ \\
5 & PSMA-CD45-pan CK & & & \\
7 & CD227-CD31-CD45-pan CK & $\sqrt{ }$ & & \\
9 & CD227-cMet-CD45-pan CK & $\sqrt{ }$ & & $\sqrt{ }$ \\
\hline
\end{tabular}


Biosciences, San Jose, CA). 50,000 events were recorded from each sample. To avoid bias, the researcher responsible for sample analysis was unaware of the samples' origin (cancerous or healthy). Analysis was performed using CFlow Plus software. Samples with low forward and side scatters were considered inappropriate and were not included in the study. Non-hematological cells were gated out using a CD45 negative selection [9]. The endothelial cells were then removed using a CD31 negative gating selection [10]. Tumor cells were identified by Pan-CK positive selection [11]. Finally, the metastatic breast, prostate and melanoma cells were analyzed for expression of c-MET, CD227, prostate-specific membrane antigen (PSMA) and CD63 [12]-[15]. Unstained and fixed samples were used as negative controls. Figure 1 and Figure 2 represent the analysis of one healthy patient and one patient with breast cancer.

\subsection{Statistical Analysis}

Prior to statistical analysis, the identity of the samples was revealed to the analyzing researcher. The data were analyzed using receiver operating characteristic (ROC) curve analysis with SPSS software [16]. The analysis was performed by one researcher to maintain accuracy. A significant $\mathrm{p}$ value was defined as $<0.05$.

\section{Results}

The samples were initially classified as either 30 positive or 30 negative based on whether they were cancerous or healthy, respectively. Flow cytometric analysis revealed that 31 samples contained CTCs and 29 did not. The data are summarized in Table 3 . The results of the present study show 0.839 area under the curve, a percentage indicating that there is $83.9 \%$ probability for a randomly selected cancerous case to be regarded with greater suspicion than a healthy one. Of the healthy donor samples, only five were positive for CTCs, which suggests that the analysis is highly sensitivity (86.2\%). In general, the sensitivity refers to the probability that a test result will be positive when the CTCs are present, while the specificity presents the probability that a test result will be negative when the CTCs are not present. The results of the present study, illustrated in Figure 3, show a specificity (true negative rate) of $83.9 \%(71.3 \%$ - 91.6\%) and sensitivity (true positive rate) $86.2 \%(72.7 \%-94.4 \%)$ when analyzing all cancer types $(\mathrm{p}<0.05)$.

Table 2. Specific antibodies used per type of cancer.

\begin{tabular}{cc}
\hline Antibody & Feature \\
\hline CD45 & Pan Leucocyte marker \\
Pan-Cytokeratin & Tumor marker \\
CD227 & Breast, lung cancer marker \\
CD63 & Melanoma marker \\
CD31 & Endothelial cell marker \\
c-Met & Metastasis marker \\
PSMA & Prostate cancer marker \\
\hline
\end{tabular}

Table 3. Summarized results of patients as true positive and false positive. "Tested" refers to the outcome from the flow cytometry experiments, while "Real" represents the data from patients' medical forms.

\begin{tabular}{ccccc}
\hline & \multicolumn{3}{c}{ Tested } & \\
\cline { 2 - 4 } Real & $\begin{array}{c}\text { Positive } \\
\text { (Cancerous) }\end{array}$ & $\begin{array}{c}\text { Negative } \\
\text { (Healthy) }\end{array}$ & Total \\
\hline \multirow{3}{*}{$\begin{array}{c}\text { Positive } \\
\text { (Cancerous) } \\
\text { Negative } \\
\text { (Healthy) } \\
\text { Total }\end{array}$} & 26 & 4 & 30 \\
& 31 & 25 & 30 \\
\hline
\end{tabular}



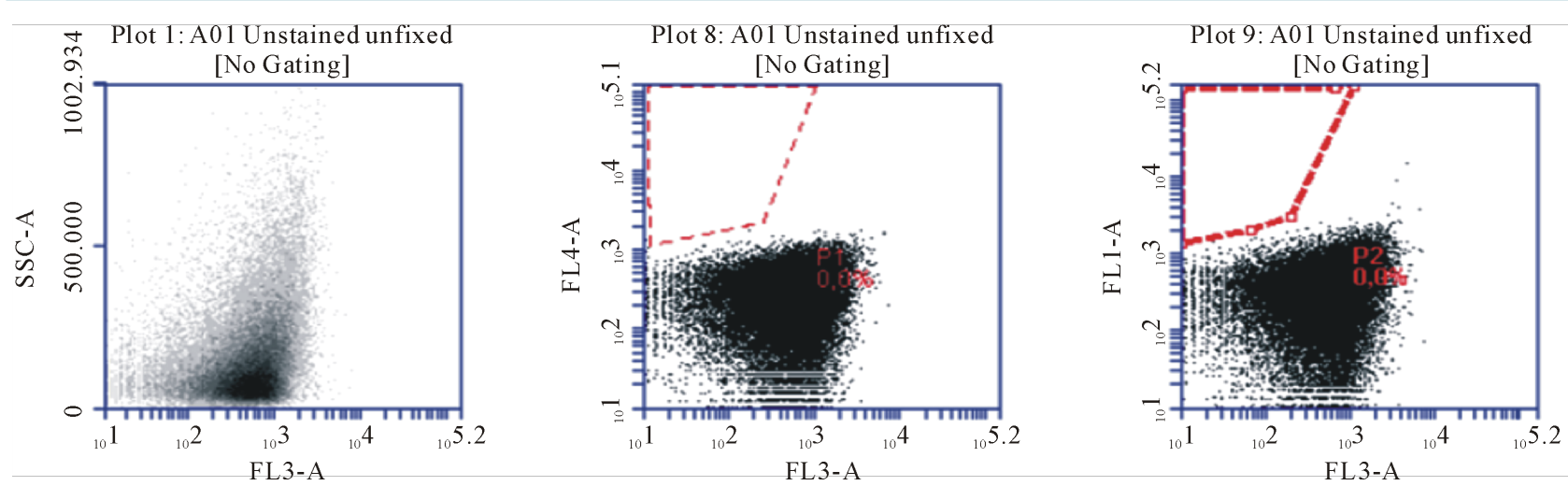

(a)

\begin{tabular}{|c|c|c|c|c|c|c|c|c|c|c|}
\hline $\begin{array}{l}\square \text { Plot 1: A01 Unstained } \\
\text { unfixed }\end{array}$ & Count & Volume $(\mu \mathrm{L})$ & $\%$ of This Plot & $\%$ of All & Mean FL3-A & Mean SSC-A & CVFL3-A & CV SSC-A & $\begin{array}{l}\text { Median } \\
\text { FL3-A }\end{array}$ & $\begin{array}{l}\text { Median } \\
\text { SSC-A }\end{array}$ \\
\hline All & 50.000 & 1 & $100.00 \%$ & $100.00 \%$ & 571.33 & 143113.16 & $91.66 \%$ & $87.57 \%$ & & \\
\hline $\begin{array}{l}\square \text { Plot 8:A01 Unstained } \\
\text { unfixed }\end{array}$ & Count & Volume $(\mu \mathrm{L})$ & $\%$ of This Plot & $\%$ of All & Mean FL3-A & Mean FL4-A & CVFL3-A & CVFL4-A & $\begin{array}{l}\text { Median } \\
\text { FL3-A }\end{array}$ & $\begin{array}{l}\begin{array}{l}\text { Median } \\
\text { FL4-A }\end{array} \\
\end{array}$ \\
\hline \begin{tabular}{|cc} 
All \\
\end{tabular} & 50.000 & 1 & $100.00 \%$ & $100.00 \%$ & 571.33 & 233.53 & $91.66 \%$ & $94.24 \%$ & & \\
\hline P1 & $\begin{array}{l}0 \\
\end{array}$ & 1 & $0.00 \%$ & $0.00 \%$ & 0.00 & 0.00 & $0.00 \%$ & $0.00 \%$ & & \\
\hline $\begin{array}{l}\text { Plot 9:A01 Unstained } \\
\text { unfixed }\end{array}$ & Count & Volume $(\mu \mathrm{L})$ & $\%$ of This Plot & $\%$ of All & Mean FL3-A & Mean FL1-A & CVFL3-A & CVFL1-A & $\begin{array}{l}\text { Median } \\
\text { FL3-A }\end{array}$ & $\begin{array}{l}\text { Median } \\
\text { FL1-A }\end{array}$ \\
\hline All & 50.000 & 1 & $100.00 \%$ & $100.00 \%$ & 571.33 & 301.93 & $91.66 \%$ & $100.99 \%$ & & \\
\hline P2 & 0 & 1 & $0.00 \%$ & $0.00 \%$ & 0.00 & 0.00 & $0.00 \%$ & $0.00 \%$ & & \\
\hline
\end{tabular}

(b)
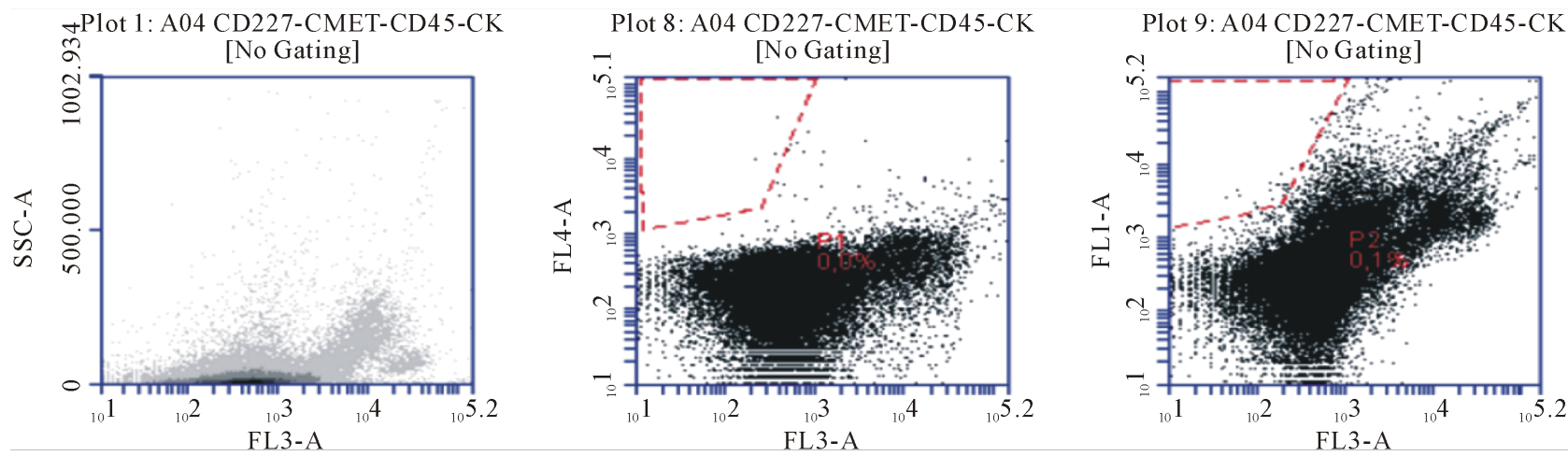

(c)

\begin{tabular}{|c|c|c|c|c|c|c|c|c|c|c|}
\hline $\begin{array}{l}\square \text { Plot 1:A04 } \\
\text { CD227-CMET-CD45-CK }\end{array}$ & Count & Volume $(\mu \mathrm{L})$ & $\%$ of This Plot & $\%$ of All & Mean FL3-A & Mean SSC-A & CVFL3-A & CV SSC-A & $\begin{array}{l}\text { Median } \\
\text { FL3-A }\end{array}$ & $\begin{array}{l}\text { Median } \\
\text { SSC-A }\end{array}$ \\
\hline All & 50.000 & 37 & $100.00 \%$ & $100.00 \%$ & 2258.12 & 31516.49 & $1174.85 \%$ & $521.79 \%$ & & \\
\hline $\begin{array}{l}\square \text { Plot 8:A04 } \\
\text { CD227-CMET-CD45-CK }\end{array}$ & Count & Volume $(\mu \mathrm{L})$ & $\%$ of This Plot & $\%$ of All & Mean FL3-A & Mean FL4-A & CV FL3-A & CVFL4-A & $\begin{array}{l}\text { Median } \\
\text { FL3-A }\end{array}$ & $\begin{array}{l}\text { Median } \\
\text { FL4-A }\end{array}$ \\
\hline All & 50.000 & 37 & $100.00 \%$ & $100.00 \%$ & 2258.12 & 538.89 & $1174.85 \%$ & $4653.15 \%$ & & \\
\hline P1 & 3 & 37 & $0.01 \%$ & $0.01 \%$ & 323.33 & 18940.33 & $23.34 \%$ & $61.33 \%$ & & \\
\hline $\begin{array}{l}\text { Plot 9:A04 } \\
\text { CD227-CMET-CD45-CK }\end{array}$ & Count & Volume $(\mu \mathrm{L})$ & $\%$ of This Plot & $\%$ of All & Mean FL3-A & Mean FL1-A & CV FL3-A & CVFL1-A & $\begin{array}{l}\text { Median } \\
\text { FL3-A }\end{array}$ & $\begin{array}{l}\text { Median } \\
\text { FL1-A }\end{array}$ \\
\hline All & 50.000 & 37 & $100.00 \%$ & $100.00 \%$ & 2258.12 & 1776.47 & $1174.85 \%$ & $2844.81 \%$ & & \\
\hline P2 & 34 & 37 & $0.07 \%$ & $0.07 \%$ & 211.35 & 9381.38 & $\begin{array}{l}64.28 \% \\
\end{array}$ & $\begin{array}{l}129.35 \% \\
\end{array}$ & & \\
\hline
\end{tabular}

(d)

Figure 1. Flow cytometric analysis of a breast cancer sample. Unstained fixed cells (a) and stained cells (c). The first plot analyzes cell granularity and CD45 expression. The second plot indicates the gate used to identify PanCytokeratin (FL4) positive and CD45 (FL3) negative cells. The final plot demonstrates the gate used to identify CD227 (FL1) positive and CD45 negative cells. (b) Statistical analysis of the unstained cells using the above gates. (d) Statistical analysis of the stained cells using the above gates. 

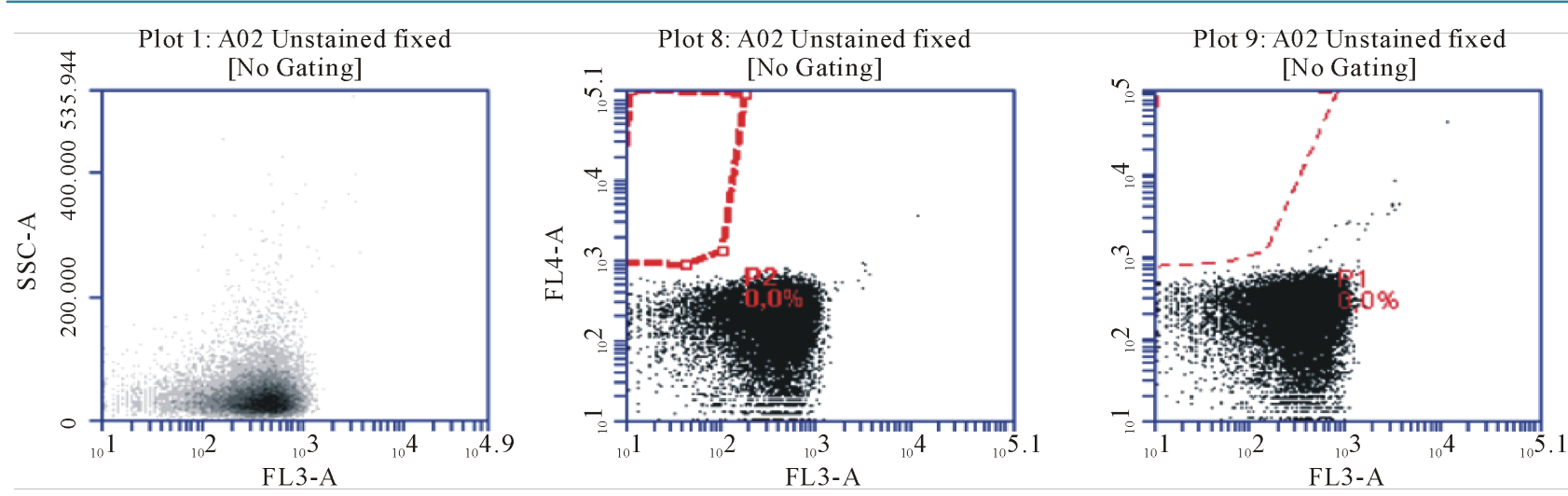

(a)

\begin{tabular}{|c|c|c|c|c|c|c|c|c|c|c|}
\hline $\begin{array}{l}\text { Plot 1:A02 Unstained } \\
\text { unfixed }\end{array}$ & Count & Volume $(\mu \mathrm{L})$ & $\%$ of This Plot & $\%$ of All & Mean FL3-A & Mean SSC-A & CVFL3-A & CV SSC-A & $\begin{array}{l}\text { Median } \\
\text { FL3-A }\end{array}$ & $\begin{array}{l}\text { Median } \\
\text { SSC-A }\end{array}$ \\
\hline All & 20.000 & 3 & $100.00 \%$ & $100.00 \%$ & 381.10 & 40658.24 & $68.34 \%$ & $138.63 \%$ & & \\
\hline $\begin{array}{l}\text { Plot 8:A02 Unstained } \\
\text { unfixed }\end{array}$ & Count & Volume $(\mu \mathrm{L})$ & $\%$ of This Plot & $\%$ of All & Mean FL3-A & Mean FL4-A & CV FL3-A & CV FL4-A & $\begin{array}{l}\text { Median } \\
\text { FL3-A }\end{array}$ & $\begin{array}{l}\text { Median } \\
\text { FL4-A }\end{array}$ \\
\hline All & 20.000 & 3 & $100.00 \%$ & $100.00 \%$ & 381.10 & 182.64 & $68.34 \%$ & $73.24 \%$ & & \\
\hline $\mathrm{P} 2$ & $\begin{array}{l}0 \\
\end{array}$ & 3 & $0.00 \%$ & $0.00 \%$ & 0.00 & 0.00 & $0.00 \%$ & $0.00 \%$ & & \\
\hline $\begin{array}{l}\text { P Plot 9:A02 Unstained } \\
\text { unfixed }\end{array}$ & Count & Volume $(\mu \mathrm{L})$ & $\%$ of This Plot & $\%$ of All & Mean FL3-A & Mean FL 1-A & CV FL3-A & CVFL1-A & $\begin{array}{l}\text { Median } \\
\text { FL3-A }\end{array}$ & $\begin{array}{l}\begin{array}{l}\text { Median } \\
\text { FL1-A }\end{array} \\
\end{array}$ \\
\hline All & 20.000 & 3 & $100.00 \%$ & $100.00 \%$ & 381.10 & 207.86 & $68.34 \%$ & $163.54 \%$ & & \\
\hline P1 & 0 & 3 & $0.00 \%$ & $0.00 \%$ & 0.00 & 0.00 & $0.00 \%$ & $0.00 \%$ & & \\
\hline
\end{tabular}

(b)
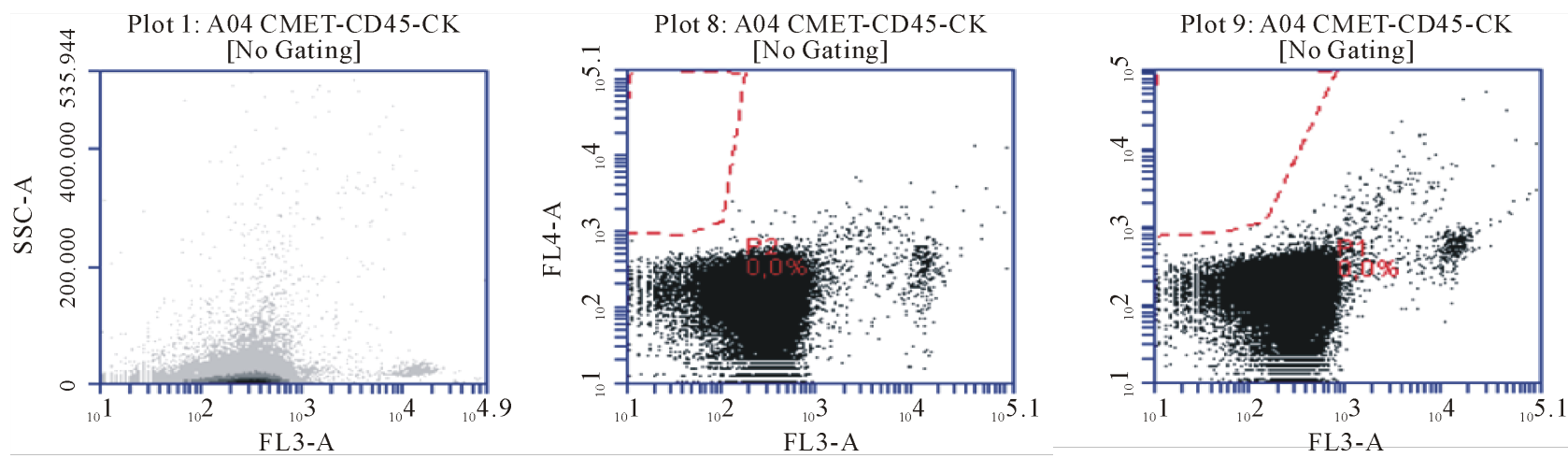

(c)

\begin{tabular}{|c|c|c|c|c|c|c|c|c|c|c|}
\hline $\begin{array}{l}\square \text { Plot 1:A04 } \\
\text { CMET-CD45-CK }\end{array}$ & Count & Volume $(\mu \mathrm{L})$ & $\%$ of This Plot & $\%$ of All & Mean FL3-A & Mean SSC-A & CV FL3-A & CV S SC-A & $\begin{array}{l}\text { Median } \\
\text { FL3-A }\end{array}$ & $\begin{array}{l}\text { Median } \\
\text { SSC-A }\end{array}$ \\
\hline All & 50.000 & 15 & $100.00 \%$ & $100.00 \%$ & 470.35 & 13337.40 & $1468.75 \%$ & $925.32 \%$ & & \\
\hline $\begin{array}{l}\text { Plot 8:A04 } \\
\text { CMET-CD45-CK }\end{array}$ & Count & Volume $(\mu \mathrm{L})$ & $\%$ of This Plot & $\%$ of All & Mean FL3-A & Mean FL4-A & CV FL3-A & CV FL4-A & $\begin{array}{l}\text { Median } \\
\text { FL3-A }\end{array}$ & $\begin{array}{l}\text { Median } \\
\text { FL4-A }\end{array}$ \\
\hline All & 50.000 & 15 & $100.00 \%$ & $100.00 \%$ & \begin{tabular}{ll|}
470.35 \\
\end{tabular} & 521.27 & $1468.75 \%$ & $5702.90 \%$ & & \\
\hline $\mathrm{P} 2$ & 0 & 15 & $0.00 \%$ & $0.00 \%$ & 0.00 & 0.00 & $0.00 \%$ & $0.00 \%$ & & \\
\hline $\begin{array}{l}\text { Plot 9:A04 } \\
\text { CMET-CD45-CK }\end{array}$ & Count & Volume $(\mu \mathrm{L})$ & $\%$ of This Plot & $\%$ of All & Mean FL3-A & Mean FL1-A & CV FL3-A & CVFL1-A & $\begin{array}{l}\text { Median } \\
\text { FL3-A }\end{array}$ & $\begin{array}{l}\text { Median } \\
\text { FL1-A }\end{array}$ \\
\hline All & 50.000 & 15 & $100.00 \%$ & $100.00 \%$ & 470.35 & 191.34 & $1468.75 \%$ & $1423.76 \%$ & & \\
\hline P1 & 0 & 15 & $\begin{array}{l}0.00 \% \\
\end{array}$ & $0.00 \%$ & $\begin{array}{l}0.00 \\
\end{array}$ & 0.00 & $0.00 \%$ & $0.00 \%$ & & \\
\hline
\end{tabular}

(d)

Figure 2. Flow cytometric analysis of a healthy sample. Unstained fixed cells (a) and stained cells (c). The first plot analyzes cell granularity and CD45 expression. The second plot indicates the gate used to identify PanCytokeratin (FL4) positive and CD45 (FL3) negative cells. The final plot demonstrates the gate used to identify CD227 (FL1) positive and CD45 negative cells. (b) Statistical analysis of the unstained cells using the above gates. (d) Statistical analysis of the stained cells using the above gates. 


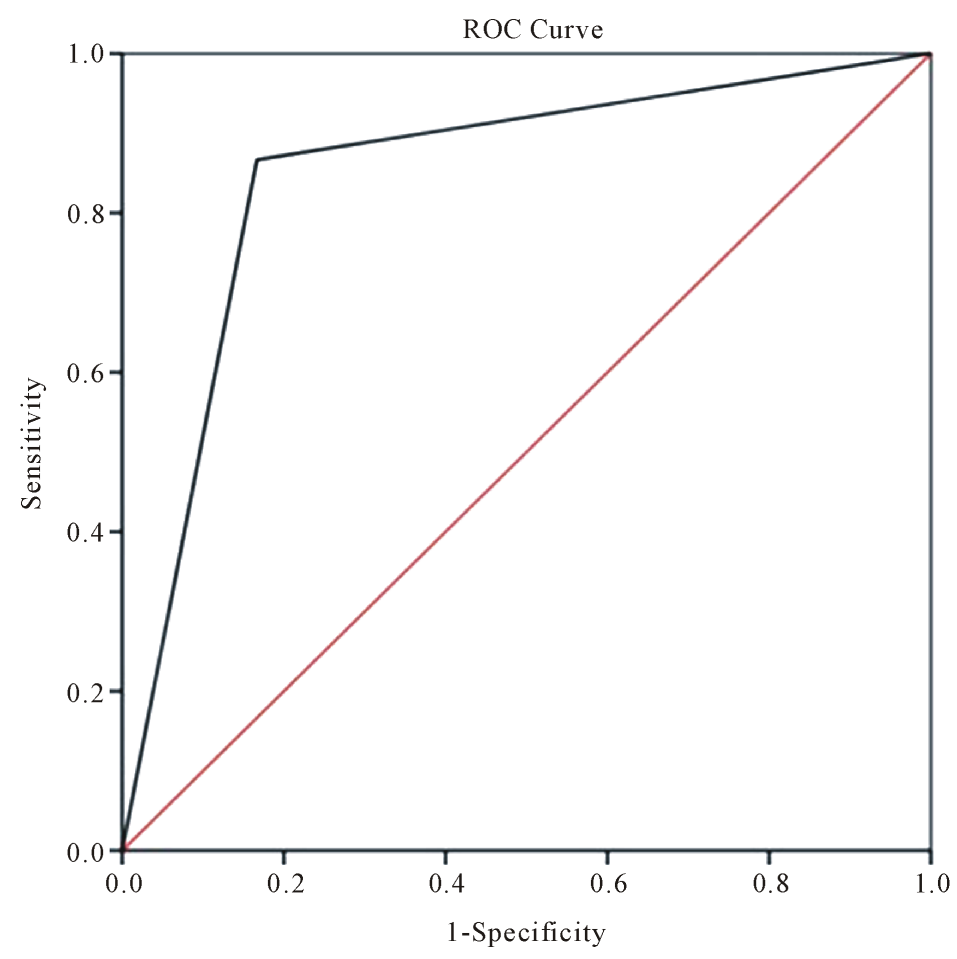

Figure 3. ROC curve analysis of samples. The present figure represents the true positive rate (sensitivity) together with the false positive rate (1specificity). The black line indicates the change of the above parameters. The point which is nearest to the upper-left corner indicates the distinguish percentage of the method, which means the ability of the method to distinct the patients from normal samples. The confidence interval was set to $95 \%$ both for sensitivity and specificity.

\section{Discussion}

Cancer cases are increasing at an exponential rate every year. Because of the frequency of new cancer cases each year, it is essential for scientists to develop techniques to diagnose patients early. Preferably, the developed techniques will identify cancer cells in body liquids so that more invasive strategies, such as biopsies, are not required. Blood is one such liquid that can easily be obtained to identify the presence of cancer [17] [18].

Several markers associated with cancer are analyzed in the blood, such as CA 15-3 for breast cancer, CA 19-9 for pancreatic, stomach and bile duct cancer, CA-125 for ovarian cancer, prostrate-specific antigen for prostate cancer and carcinoembryonic antigen for colorectal cancer [19]. However, these markers have limitations, the most important being their tendency to be detectable only when the tumor-burden is severe [20]. For that reason, evaluating alternative methods to detect carcinogenesis at its early stages and provide reliable and accurate results is essential.

CTCs are cells that have entered the blood after being detached from the primary tumor [21]. These cells are believed to play a crucial role in metastasis and cancer progression [22]-[24]. Therefore, detecting and monitoring CTCs is useful for prognosis and predicting disease progression and response to treatment, and several different methods have been developed to identify CTCs [25]-[27].

Because CTCs are rare in the circulation ( 1 in $10^{9}$ blood cells), methods applied to assess them face many challenge [8]. Current techniques to isolate and enumerate CTCs do so based on their physical properties or morphological features. Other technologies use PCR-based methods or antibodies directed against epithelial cell adhesion molecules (EpCAM) on the cell surface of CTCs [4]. However, the above methods have limitations. Specifically, the cytomorphology of CTCs is not consistent, the PCR-based method does not enable the cells to be further analyzed and the antibody bead-based assays are limited by the availability of specific antibodies.

The only Food and Drug Administration-approved method for detecting CTCs is the CellSearch system, 
which is currently considered the "gold standard". This platform is a magnetic-bead-based assay that uses EpCAM antibodies to enrich the epithelial cells from the blood, as CTCs demonstrate epithelial origin [28]-[30]. Briefly, CTCs are magnetically separated from other cells, are stained with cytokeratin monoclonal antibodies cells and identification of contaminating leukocytes follows. Then the nuclei of CTCs are stained with DAPI and the cells are enumerated. The drawback of this method is that a proportion of CTCs may be lost during enrichment due to lack of EpCAM expression (false negatives) [31].

The aim of this study was to improve the recovery and performance of CTC detection and enumeration in compare with previous study whose sensitivity varies from $26 \%$ to $57 \%$. The main difference between the present study and the recommended gold standard is that blood samples were not spiked with tumor cells, in order to determine the specificity [6] [25]. With the new method, only the tumor cells already in the blood of cancer patients were detected. Another significant difference is that the present study was blind, which means that sample encoding was performed by one scientist and the researcher responsible for data analysis was unaware of whether the sample was from a healthy patient. Finally, in the present study a number of biomarker specific for different types of cancer (CD227 for breast cancer, CD63 for melanomas, PSMA for prostate cancer and c-MET for metastatic cells) were used to make the analysis specific for each cancer type. EpCAM is the most common marker used for the identification of tumor cells; however, a number of other epitopes are currently used in tumor detection [32]. Mucins cover the surface of epithelial cells in several organs and protect the body from infection. Overexpression of the glycoprotein CD227 (Mucin-1 or CA 15-3) is often associated with colon, breast, ovarian, lung and pancreatic cancers [33]. CD63 is a member of the transmembrane 4 superfamily, also known as the tetraspanin family. These proteins mediate signal transduction events that play a role in the regulation of cell development, activation, growth and motility. CD63 has been shown to regulate melanoma cell growth and motility [34] [35]. PSMA is an enzyme that, in humans, is encoded by the FOLH1 (folate hydrolase 1) gene. In prostate cancer it is the second most upregulated gene, with an increase of 8 - 12-fold higher than the noncancerous prostate. Because of this high expression, therapies and imaging strategies are being developed to target FOLH1 [36]. c-Met, also called hepatocyte growth factor receptor, is normally expressed by epithelial cells. Abnormal c-MET activation in cancer correlates with poor prognosis and triggers tumor proliferation, neovascularization and metastases. Therefore, c-Met-positive cells are of interest [37]. The expression of cytokeratins by cells is organ and tissue specific. Moreover, the cytokeratin profile tends to remain intact when an epithelial cell undergoes a malignant transformation. Therefore, analyzing the cytokeratin profile of tumor cells is helpful for tumor characterization [26].

\section{Conclusion}

In conclusion, this study demonstrates that it is possible to detect CTCs with higher sensitivity (86.2\%) and specificity (83.9\%) compared with routine clinical methodologies. The parameters may vary depending on the antibody panel used; however, using flow cytometry to identify CTCs has proven to be efficient. These results suggest that further studies are required to improve the accuracy by which CTCs and CTC subtypes can be identified by flow cytometry and thereby improve our ability to detect and follow the progression of cancer.

\section{Conflict of Interest}

The authors declare that they have no conflict of interest.

\section{References}

[1] Siegel, R., Ma, J., Zou, Z. and Jemal, A. (2014) Cancer Statistics, 2014. CA: A Cancer Journal for Clinicians, 64, 9-29. http://dx.doi.org/10.3322/caac.21208

[2] Chaffer, C.L. and Weinberg, R.A. (2011) A Perspective on Cancer Cell Metastasis. Science, 331, 1559-1564. http://dx.doi.org/10.1126/science.1203543

[3] Chambers, A.F., Groom, A.C. and MacDonald, I.C. (2002) Dissemination and Growth of Cancer Cells in Metastatic Sites. Nature Reviews Cancer, 2, 563-572. http://dx.doi.org/10.1038/nrc865

[4] Williams, S.C. (2013) Circulating Tumor Cells. Proceedings of the National Academy of Sciences of the USA, 110, 4861. http://dx.doi.org/10.1073/pnas.1304186110

[5] Plaks, V., Koopman, C.D. and Werb, Z. (2013) Cancer. Circulating Tumor Cells. Science, 341, 1186-1188. http://dx.doi.org/10.1126/science.1235226 
[6] Miller, M.C., Doyle, G.V. and Terstappen, L.W. (2010) Significance of Circulating Tumor Cells Detected by the CellSearch System in Patients with Metastatic Breast Colorectal and Prostate Cancer. Journal of Oncology, 2010, Article ID: 617421. http://dx.doi.org/10.1155/2010/617421

[7] Smirnov, D.A., Zweitzig, D.R., Foulk, B.W., Miller, M.C., Doyle, G.V., Pienta, K.J., Meropol, N.J., Weiner, L.M., Cohen, S.J., Moreno, J.G., et al. (2005) Global Gene Expression Profiling of Circulating Tumor Cells. Cancer Research, 65, 4993-4997. http://dx.doi.org/10.1158/0008-5472.CAN-04-4330

[8] Stott, S.L., Hsu, C.H., Tsukrov, D.I., Yu, M., Miyamoto, D.T., Waltman, B.A., Rothenberg, S.M., Shah, A.M., Smas, M.E., Korir, G.K., et al. (2010) Isolation of Circulating Tumor Cells Using a Microvortex-Generating HerringboneChip. Proceedings of the National Academy of Sciences of the USA, 107, 18392-18397. http://dx.doi.org/10.1073/pnas.1012539107

[9] Gredelj-Simec, N., Jelic-Puskaric, B., Ostojic, A., Siftar, Z., Fiala, D., Kardum-Skelin, I., Vrhovac, R. and Jaksic, B. (2011) Diagnostic and Prognostic Significance of CD45 Cell Surface Antigen Expression in Hematologic Malignancies with Main Focus on Acute Leukemias. Acta Medica Croatica, 65, 45-52.

[10] Liu, L. and Shi, G.P. (2012) CD31: Beyond a Marker for Endothelial Cells. Cardiovascular Research, 94, 3-5. http://dx.doi.org/10.1093/cvr/cvs108

[11] Sorenson, S.C., Asch, B.B., Connolly, J.L., Burstein, N.A. and Asch, H.L. (1987) Structural Distinctions among Human Breast Epithelial Cells Revealed by the Monclonal Antikeratin Antibodies AE1 and AE3. The Journal of Pathology, 153, 151-162. http://dx.doi.org/10.1002/path.1711530208

[12] Gentile, A., Trusolino, L. and Comoglio, P.M. (2008) The Met Tyrosine Kinase Receptor in Development and Cancer. Cancer and Metastasis Reviews, 27, 85-94. http://dx.doi.org/10.1007/s10555-007-9107-6

[13] Hollingsworth, M.A. and Swanson, B.J. (2004) Mucins in Cancer: Protection and Control of the Cell Surface. Nature Reviews Cancer, 4, 45-60. http://dx.doi.org/10.1038/nrc1251

[14] Maria, T., Panagiotis, A., Marina, C., Eleni, K., Ioanna, V., Georgia, M. and Ioannis, P. (2014) How Prostate-Specific Membrane Antigen Level May Be Correlated with Stemness in Prostate Cancer Stem Cell-Like Cell Populations? Journal of Cancer Research and Therapeutics, 10, 133-141. http://dx.doi.org/10.4103/0973-1482.131461

[15] Radford, K.J., Thorne, R.F. and Hersey, P. (1996) CD63 Associates with Transmembrane 4 Superfamily Members, CD9 and CD81, and with Beta 1 Integrins in Human Melanoma. Biochemical and Biophysical Research Communications, 222, 13-18. http://dx.doi.org/10.1006/bbrc.1996.0690

[16] Linden, A. (2006) Measuring Diagnostic and Predictive Accuracy in Disease Management: An Introduction to Receiver Operating Characteristic (ROC) Analysis. Journal of Evaluation in Clinical Practice, 12, 132-139. http://dx.doi.org/10.1111/j.1365-2753.2005.00598.x

[17] Mitchell, P.S., Parkin, R.K., Kroh, E.M., Fritz, B.R., Wyman, S.K., Pogosova-Agadjanyan, E.L., Peterson, A., Noteboom, J., O’Briant, K.C., Allen, A., et al. (2008) Circulating microRNAs as Stable Blood-Based Markers for Cancer Detection. Proceedings of the National Academy of Sciences of the United States of America, 105, 10513-10518. http://dx.doi.org/10.1073/pnas.0804549105

[18] Toloudi, M., Apostolou, P., Chatziioannou, M. and Papasotiriou, I. (2011) Correlation between Cancer Stem Cells and Circulating Tumor Cells and Their Value. Case Reports in Oncology, 4, 44-54. http://dx.doi.org/10.1159/000324403

[19] Pilo, A., Zucchelli, G.C., Cohen, R., Bizollon, C.A., Cappelli, G., Cianetti, A., Gion, M., Piffanelli, A. and Bombardieri, E. (1995) Comparison of Immunoassays for Tumor Markers CA 19-9, CA 15-3 and CA 125: Data from an International Quality Assessment Scheme. Tumori, 81, 117-124.

[20] Duffy, M.J. (2001) Clinical Uses of Tumor Markers: A Critical Review. Critical Reviews in Clinical Laboratory Sciences, 38, 225-262. http://dx.doi.org/10.1080/20014091084218

[21] Tibbe, A.G., Miller, M.C. and Terstappen, L.W. (2007) Statistical Considerations for Enumeration of Circulating Tumor Cells. Cytometry Part A, 71, 154-162. http://dx.doi.org/10.1002/cyto.a.20369

[22] Hermann, P.C., Huber, S.L., Herrler, T., Aicher, A., Ellwart, J.W., Guba, M., Bruns, C.J. and Heeschen, C. (2007) Distinct Populations of Cancer Stem Cells Determine Tumor Growth and Metastatic Activity in Human Pancreatic Cancer. Cell Stem Cell, 1, 313-323. http://dx.doi.org/10.1016/j.stem.2007.06.002

[23] Kalluri, R. and Weinberg, R.A. (2009) The Basics of Epithelial-Mesenchymal Transition. Journal of Clinical Investigation, 119, 1420-1428. http://dx.doi.org/10.1172/JCI39104

[24] Mani, S.A., Guo, W., Liao, M.J., Eaton, E.N., Ayyanan, A., Zhou, A.Y., Brooks, M., Reinhard, F., Zhang, C.C., Shipitsin, M., et al. (2008) The Epithelial-Mesenchymal Transition Generates Cells with Properties of Stem Cells. Cell, 133, 704-715. http://dx.doi.org/10.1016/j.cell.2008.03.027

[25] Riethdorf, S., Fritsche, H., Muller, V., Rau, T., Schindlbeck, C., Rack, B., Janni, W., Coith, C., Beck, K., Janicke, F., et al. (2007) Detection of Circulating Tumor Cells in Peripheral Blood of Patients with Metastatic Breast Cancer: A Validation Study of the Cell Search System. Clinical Cancer Research, 13, 920-928. 
http://dx.doi.org/10.1158/1078-0432.CCR-06-1695

[26] Marrinucci, D., Bethel, K., Lazar, D., Fisher, J., Huynh, E., Clark, P., Bruce, R., Nieva, J. and Kuhn, P. (2010) Cytomorphology of Circulating Colorectal Tumor Cells: A Small Case Series. Journal of Oncology, 2010, Article ID: 861341. http://dx.doi.org/10.1155/2010/861341

[27] Meng, S., Tripathy, D., Frenkel, E.P., Shete, S., Naftalis, E.Z., Huth, J.F., Beitsch, P.D., Leitch, M., Hoover, S., Euhus, D., et al. (2004) Circulating Tumor Cells in Patients with Breast Cancer Dormancy. Clinical Cancer Research, 10, 8152-8162. http://dx.doi.org/10.1158/1078-0432.CCR-04-1110

[28] Allard, W.J., Matera, J., Miller, M.C., Repollet, M., Connelly, M.C., Rao, C., Tibbe, A.G., Uhr, J.W. and Terstappen, L.W. (2004) Tumor Cells Circulate in the Peripheral Blood of All Major Carcinomas but Not in Healthy Subjects or Patients with Nonmalignant Diseases. Clinical Cancer Research, 10, 6897-6904. http://dx.doi.org/10.1158/1078-0432.CCR-04-0378

[29] Momburg, F., Moldenhauer, G., Hammerling, G.J. and Moller, P. (1987) Immunohistochemical Study of the Expression of a Mr 34,000 Human Epithelium-Specific Surface Glycoprotein in Normal and Malignant Tissues. Cancer Research, 47, 2883-2891.

[30] Pachmann, K., Camara, O., Kavallaris, A., Krauspe, S., Malarski, N., Gajda, M., Kroll, T., Jorke, C., Hammer, U., Altendorf-Hofmann, A., et al. (2008) Monitoring the Response of Circulating Epithelial Tumor Cells to Adjuvant Chemotherapy in Breast Cancer Allows Detection of Patients at Risk of Early Relapse. Journal of Clinical Oncology, 26, 1208-1215. http://dx.doi.org/10.1200/JCO.2007.13.6523

[31] Cristofanilli, M. (2009) The Biological Information Obtainable from Circulating Tumor Cells. The Breast, 18, S38-S40. http://dx.doi.org/10.1016/s0960-9776(09)70270-X

[32] Sterzynska, K., Kempisty, B., Zawierucha, P. and Zabel, M. (2012) Analysis of the Specificity and Selectivity of Anti-EpCAM Antibodies in Breast Cancer Cell Lines. Folia Histochemica et Cytobiologica, 50, 534-541. http://dx.doi.org/10.5603/FHC.2012.0075

[33] Moncada, D.M., Kammanadiminti, S.J. and Chadee, K. (2003) Mucin and Toll-Like Receptors in Host Defense against Intestinal Parasites. Trends in Parasitology, 19, 305-311. http://dx.doi.org/10.1016/S1471-4922(03)00122-3

[34] Wang, M.X., Earley Jr., J.J., Shields, J.A. and Donoso, L.A. (1992) An Ocular Melanoma-Associated Antigen. Molecular Characterization. Archives of Ophthalmology, 110, 399-404. http://dx.doi.org/10.1001/archopht.1992.01080150097036

[35] Iida, J., Skubitz, A.P., McCarthy, J.B. and Skubitz, K.M. (2005) Protein Kinase Activity Is Associated with CD63 in Melanoma Cells. Journal of Translational Medicine, 3, 42. http://dx.doi.org/10.1186/1479-5876-3-42

[36] O’Keefe, D.S., Bacich, D.J. and Heston, W.D. (2004) Comparative Analysis of Prostate-Specific Membrane Antigen (PSMA) versus a Prostate-Specific Membrane Antigen-Like Gene. Prostate, 58, 200-210. http://dx.doi.org/10.1002/pros.10319

[37] Bardelli, A., Corso, S., Bertotti, A., Hobor, S., Valtorta, E., Siravegna, G., Sartore-Bianchi, A., Scala, E., Cassingena, A., Zecchin, D., et al. (2013) Amplification of the MET Receptor Drives Resistance to Anti-EGFR Therapies in Colorectal Cancer. Cancer Discovery, 3, 658-673. http://dx.doi.org/10.1158/2159-8290.CD-12-0558 


\section{Abbreviation List}

CTCs: Circulating tumor cells

ROC: Receiver operating characteristic

EpCAM: Epithelial cell adhesion molecule

EDTA: Ethylenediaminetetraacetic acid

Cy5.5: Cyanine 5.5

FITC: Fluorescein isothiocyanate

RPE: R Phycoerythrin

PE-Cy 7: Phycoerythrin cyanine 7

CD: Cluster of differentiation

PSMA: Prostate-specific membrane antigen

CA: Cancer antigen

DAPI: 4',6-diamidino-2-phenylindole

FOLH1: Folate hydrolase 1 